\title{
A STUDY ON THE PRODUCTION AND MARKETING OF BEE PRODUCTS PROVIDING BIODIVERSITY: CASE STUDY FROM TURKEY
}

\author{
ÇUKUR, F. $^{1}-$ ÇUKUR, T. ${ }^{2 *}$ \\ ${ }^{I}$ Department of Management and Organization, Milas Vocational School, Muğla Sitkı Koçman \\ University, 48200 Milas, Muğla, Turkey \\ ${ }^{2}$ Department of Marketing and Advertising, Milas Vocational School, Muğla Sitkı Koçman \\ University, 48200 Milas, Muğla, Turkey \\ *Corresponding author \\ e-mail: tayfun.cukur@hotmail.com; phone: +90-252-211-3263; fax: +90-252-211-1879 \\ (Received $3^{\text {rd }}$ Jan 2019; accepted 28 ${ }^{\text {th }}$ Feb 2019)
}

\begin{abstract}
This research aims to find out the marketing problems of the beekeepers in Muğla province, Milas district of Turkey and offer potential solutions. The main material of the research is the data gained via surveys, performed as face-to-face interviews with beekeeping farmers in Milas district. According to the data of Milas District Agriculture and Forestry Directorate, 721 beekeepers constitute the main part of the research. The proportional sample size has been determined as 62 people. The most significant problems that farmers face during the production are diseases and pests by $53.2 \%$, while the most significant problem during marketing is the low selling price of honey by $80.6 \%$.
\end{abstract}

Keywords: beekeeping, beekeepers, honey, economy, price

\section{Introduction}

Beekeeping is seen as a strategically important sector that should be supported in order to protect biodiversity and transfer it to next generations, provide food security, increase diversity, support domestic economy by increasing employment, and prevent erosion threat (Y1lmaz, 2015).

Global climate change is one of the most important problems facing today's societies. The agricultural sector, which meets the food, nutrition and fiber needs of the society, is one of the most vulnerable sectors against climate change (Arbuckle et al., 2013). Honey bee is the most valuable pollinator of agricultural products worldwide economically. Approximately $73 \%$ of the plants cultured in the world are pollinated by bees (Reddy et al., 2012). One of the main factors affecting honey production is the climate (Malisa and Yanda, 2015). That is, beekeeping sector is dramatically affected by drought and climate change. Sustainability of soil and water resources is of vital importance for beekeeping. Sustainability of soil and water resources is of vital importance for beekeeping because the bee needs healthy vegetation and flora. On the other hand, seasonal effects of global warming negatively affect bees. The effect of climate change on bees may cause the bees not to fulfill the function expected of them in pollination. This reduces the quality and quantity of crop production and can lead to economic loss of beekeepers.

Beekeeping is not a soil-based production field, for that reason it can be an only income source for the farmers who have no or limited land. Running with a limited budget, establishing and running the business with low expenses, generating income in short terms, marketing bee products easily and providing bee and bee breeds 
domestically are the most significant reasons that make beekeeping attractive (OGM, 2013).

Beekeeping activities which is an important sub-sector of livestock provides a prominent added value. As a sub-sector of livestock and agriculture, beekeeping activity creates a significant added value for the economy. Sustainability of the added value is directly related to developing marketing opportunities for the products and analyzing marketing problems. Besides of having great geographical features and rich flora, Turkey has a significant place in global beekeeping sector with its colony assets (Köseman et al., 2016). Beekeeping in Turkey is an agricultural occupation done to produce honey only. Most of the beekeeping businesses are family-run businesses (Şahinler and Gül, 2003).

By the year of 2016, there are 90564654 bee hives in the world and they produce 1 786996 ton honey approximately (FAO, 2018). By the same year in Turkey, these numbers are respectively 7900364 and 105727.435 tons (TSI, 2018). Namely, Turkey produces $8.72 \%$ of the hive assets and $5.92 \%$ of honey production in the world. By the year of 2017, there are 83210 beekeeping businesses in Turkey. By the same year, the number of total hives is 7991072 . In Muğla province where the research is conducted, there are 6000 families that are bekeeping farmers in 334 villages. In Muğla province, the main product of beekeeping is pine honey; and Muğla provides 70-75\% of the production in Turkey. In Muğla 35000-40000 people are employed in beekeeping sector (Şahin, 2015). By 2017, Muğla supplies $11.99 \%$ of the hive assets and $13.86 \%$ of honey production in Turkey (TSI, 2018).

Being the capital of beekeeping production, Muğla province Milas district has a significant potential in terms of beekeeping activities in Turkey. Beekeeping activities which is no longer a side income started to be basic living source for most of the families in rural areas in Milas district. By 2017, 15.39\% of the beekeeping businesses of Muğla province is located in Milas district. By 2017, 18.04\% of the natural honey produced in Muğla province and $2.06 \%$ of the beewax have been produced in Milas district. On the other hand, $17.74 \%$ of the total hive assets of Muğla province (old and new) is located in Milas district (TSI, 2018).

Main aim of the study is to indicate the structure of beekeeping production and marketing in Muğla province Milas district. Within this scope, firstly socio- economic structure of the beekeepers, the production and marketing structure of beekeeping goods produced in businesses and problems of the farmers that they face during production and marketing phase have determined; possible solution offers for the problems have suggested.

\section{Materials and methods}

\section{Study area}

The geographical position of Milas is $37^{\circ} 18^{\prime} 59^{\prime \prime}$ North and $27^{\circ} 47^{\prime} 2^{\prime \prime}$ East. Milas is located in the southwest of Turkey within the borders of Aegean Region in the Menteşe Mountainous area. Administratively, it is a central district located within the borders of Muğla province (Fig. 1). It is bordered by the city of Muğla and Yatağan district in the east, Yenihisar district of the city of Aydın in the west, Kocarl1, Karpuzlu and Çine districts in the north, Gökova Bay in the south and Bodrum district in the southwest (Çakar, et al., 2011). 
It is possible to examine agriculture in Milas as fruit and vegetable, grain and industrial plant production. Because of its climate and geographical structure, Milas is one of the rare place where many products can be grown. Its primary agricultural products are olive, forage plants, wheat, barley, grain corn, cotton, tobacco, vegetables and citrus fruits. Milas is the most important olive and olive oil production area of the Aegean region. Industrialization related to olive cultivation has been the primary key industry of Milas for a very long time. Animal husbandry is also important in the district. Beekeeping and honey production as well as fish farming have a significant for district (Anonymous, 2015).

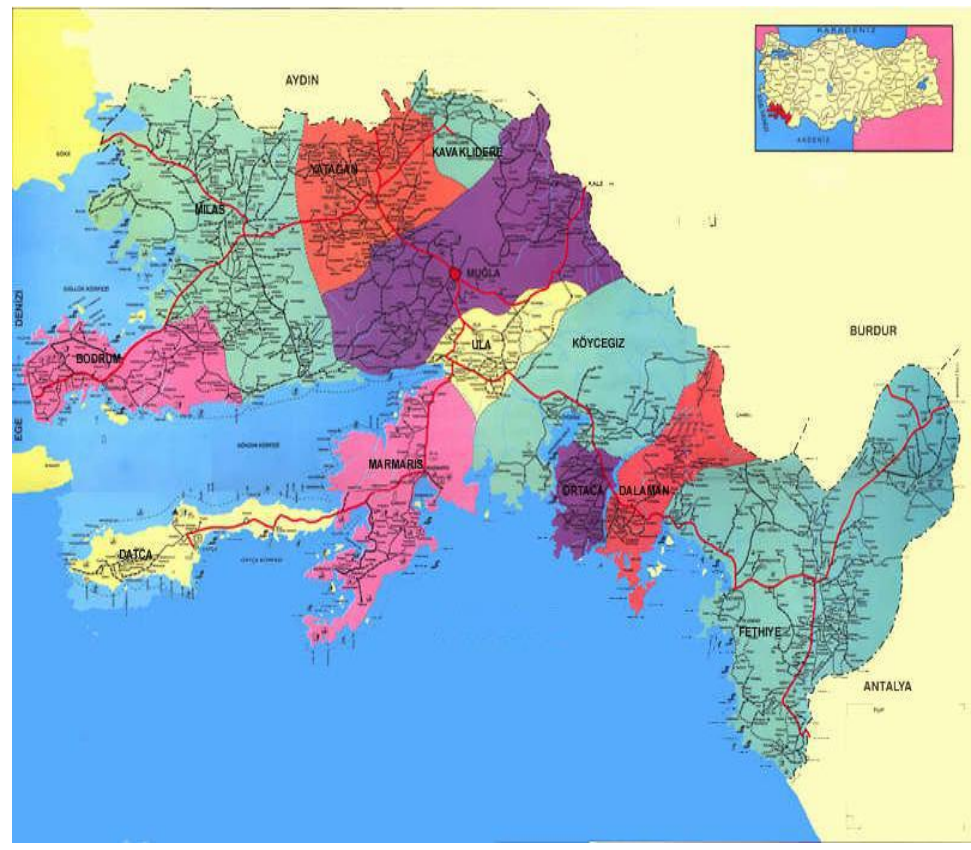

Figure 1. Map of Muğla Province. (Source: Anonymous, 2004)

\section{Method applied when collecting data}

The main material of the research is data gained via surveys with face-to-face interviews done among the beekeeping farmers in Milas district of Muğla province in Aegean Region. According to the records of Agriculture and Forestry District Directorate of Milas, 721 beekeepers constitutes the main part of the research. Having specified by proportional sample volume (Newbold, 1995), interviews were done with the farmers. $90 \%$ confidence interval and $10 \%$ error margin is taken as a basis in the research. The data of the study were obtained from the face-to-face surveys conducted with beekeepers in Milas district in April-May 2017. Nine neighbourhood (village) of the district is examined as the scope of the research.

$$
n=\frac{N p(1-p)}{(N-1) \sigma_{P}^{2}+p(1-p)}
$$

In Equation 1: $\mathrm{N}=$ total number of farmers as interview; $\mathrm{N}=$ population; $\mathrm{P}$ is taken as 0.50 to be able to reach maximum sample volume; $(1-p)=0.5 ; \sigma_{p x}{ }^{2}=$ variance. In the calculation, total number of the farmers that is to be interviewed is figured as 62 . 


\section{Method applied when analyzing data}

After acquiring the data for the research, assessment phase has been started. The data from the surveys has been coded and recorded. Definitive statistical analysis is used in order to assess the data.

\section{Results}

\section{General features of farms and farmers}

The ages of the farmers range from 27 to 74, and average age of the farmers is 48 . When it comes to adaptation of new techniques and technologies, education level of the beekeepers has an important role (Ogunjimi et al., 2016). The education level of the beekeepers participating in the current study was found to be low. In the research, average education year of the famers is figured as 5.9. Average household population of beekeepers is 3.6. It has been calculated that average agricultural experience of the farmers is 26.3 years, average experience as beekeepers is 19.5 years. It is found that $64.5 \%$ of the farmers who participated in the research took out loan. In the research, it is specified that only $9.7 \%$ of the farmers have business records regularly.

$88.7 \%$ of the farmers (55 farmers) who participated in the research have other agricultural activities than beekeeping. Average business width of the farmers is figured as 23.1 decares. It is seen in the research that five farmers have no agricultural land. It is determined that $98.2 \%$ of the beekeeping businesses continue their agricultural activities on property land, $1.8 \%$ of them continue agricultural activities on rented land. $61.8 \%$ of the farmers make mixed production (crop+animal production), 32.7\% make only crop production, 5.5\% make only animal production.

Farmers who participated in the study stated that $38.1 \%$ of their agricultural income came from beekeeping activities. 25.8\% of the farmers participating in the survey have non-agricultural income. Farmers are engaged in professions such as local headman, coffeehouse owner, fisherman, labourer apart from agriculture. There are farmers who are retired and traders, as well.

\section{Findings related to production and marketing}

$6.5 \%$ of the farmers participating this research stated that they started beekeeping with old type hive, $88.7 \%$ of them started with buying colonies with modern hives and $8.1 \%$ of them started with buying swarm.

The reasons for farmers' to do beekeeping are examined and for this purpose Table 1 is formed. The first reason of farmers' to do beekeeping is that there is no other source of income (37.1\%). This is followed by the habit inherited from family (33.9\%) and ability to access to the product in short time (29\%).

Honey can be defined as the natural product in which the plant nectars, the secretions of the alive parts of the plants or the secretions of plant-absorbing insects that live on the living parts of the plants, are collected by the honeybee (Apis mellifera) and combined with their own specific substances, decreasing the water content and storing it in the honeycomb (Anonymous, 2005). Beekeeping activities can be considered as an important rural development tool, which provides a certain rate of income to a large number of farmers, in rural areas. Undoubtedly, the first condition for farmers to earn income from beekeeping activities is that they produce clean, hygienic and good quality honey. Determination of product properties, honey additives and residue levels of honey 
produced by farmers can be measured by honey analysis. For this reason, it is very important for farmers to make honey analysis for honey they produced. In the study, it was determined that the farmers' honey analysis rate is quite low. It was determined that only two producers had honey analysis.

Table 1. Reasons for farmers to do beekeeping

\begin{tabular}{c|c|c}
\hline Reasons to do beekeeping & n & \% \\
\hline Ease of maintenance & 10 & 16.1 \\
Short production period & 18 & 29.0 \\
Habit inherited from family & 21 & 33.9 \\
Curiosity, hobby & 15 & 24.2 \\
There is no other source of income & 23 & 37.1 \\
Because the product is suitable the region & 2 & 3.2 \\
\hline
\end{tabular}

*Total passes $100 \%$ since there are more than one answer

The presence of colony in the production of bee products is of great importance. Naturally, as the number of colonies increases, the production amounts of bee products are expected to increase. For this reason, in this study, farmers' colony assets are investigated. In the study, the percentage of farmers indicating the increase in the colony assets in the last three years was $17.7 \%$ and the percentage of farmers indicating the decrease in it was $48.4 \%$ (Table 2).

Table 2. Change in the colony assets in the last three years

\begin{tabular}{c|c|c}
\hline & $\mathbf{n}$ & $\mathbf{\%}$ \\
\hline Increased & 11 & 17.7 \\
No change & 21 & 33.9 \\
Decreased & 30 & 48.4 \\
Total & 62 & 100.0 \\
\hline
\end{tabular}

The migratory beekeeping is based on the principle of transporting colonies from one region to another in order to benefit from different flowering periods in plants and to protect the bees from adverse winter conditions. $77.4 \%$ of the farmers participating in the research is doing migratory beekeeping, $22.6 \%$ is doing fixed beekeeping.

It was determined that the farmers moved their hives to various provinces such as Kayseri, Ankara, Eskişehir, Sivas, Konya, Nevşehir, Tekirdağ, Niğde, Kütahya, Afyonkarahisar, Kars, Sakarya, Edirne and Burdur. A farmer who stated that he was a fixed beekeeper stated that he had moved his hives to the neighbouring villages. It is specified that the farmers usually go in May and return in August. When the farmers' honey harvesting frequency was examined, it was concluded that half of the farmers participating in the study do harvesting twice a year. $30.6 \%$ of the farmers harvest three times a year (Table 3).

In the study, the average number of hives owned by farmers was found as 162 units. Today, beekeeping business is one of the means of living of many families in rural areas. The products obtained from beekeeping business, such as pollen, propolis, beeswax and primarily honey, provide a significant added value in the income of the 
producers engaged in beekeeping in rural areas (Çukur et al., 2016). 98.4\% of the farmers interviewed in this study were identified to produce honey, $46.8 \%$ of them produce beeswax and $29 \%$ of them produce queen bees (Table 4).

Table 3. Farmers' honey harvesting frequency

\begin{tabular}{c|c|c}
\hline & $\mathbf{n}$ & $\mathbf{\%}$ \\
\hline Once in every three weeks & 2 & 3.2 \\
Once in a month & 6 & 9.7 \\
Twice a year & 31 & 50.0 \\
Three times in a year & 19 & 30.6 \\
Four times in a year & 1 & 1.7 \\
Once in a year & 3 & 4.8 \\
Total & 62 & 100.0 \\
\hline
\end{tabular}

Table 4. Number of farmers producing bee products

\begin{tabular}{c|c|c}
\hline & $\mathbf{n}$ & $\mathbf{\%}$ \\
\hline Number of farmers producing extracted honey & 61 & 98.4 \\
Number of farmers producing comb honey & 17 & 27.4 \\
Number of farmers producing beeswax & 29 & 46.8 \\
Number of farmers producing swarm & 23 & 37.1 \\
Number of farmers producing queen bee & 18 & 29.0 \\
Number of farmers producing pollen & 7 & 11.3 \\
\hline
\end{tabular}

The average production quantities of bee products are shown in Table 5. From the farmers participated in this research, it is determined that the average amount of extracted honey production was $2334.5 \mathrm{~kg}$, the average comb honey production amount was $81 \mathrm{~kg}$ and the average beeswax production amount was $48.9 \mathrm{~kg}$. In the study, average extracted honey production per hive was calculated as $14.41 \mathrm{~kg}$.

Table 5. Average production amount of bee products

\begin{tabular}{c|c}
\hline & Production amount \\
\hline The amount of extracted honey $(\mathrm{kg})$ & 2334.5 \\
The amount of comb honey $(\mathrm{kg})$ & 81.0 \\
The amount of beeswax $(\mathrm{kg})$ & 48.9 \\
The amount of swarm (unit) & 10.2 \\
The amount of queen bee (unit) & 16.3 \\
The amount of pollen (kg) & 3.8 \\
\hline
\end{tabular}

It was specified that $87.1 \%$ of farmers have problems with honey production. Farmers who have problems with honey production are asked about their problems and Table 6 is formed according to the answers. Diseases and pests (53.2\%) and negative effects of global warming $(41.9 \%)$ are among the most important problems of beekeepers. 
Table 6. Farmers' problems related to honey production

\begin{tabular}{|c|c|c|}
\hline & $\mathbf{n}$ & $\%$ \\
\hline Diseases and pests & 33 & 53.2 \\
\hline Accommodation and safety issues in migratory beekeeping & 25 & 40.3 \\
\hline Negative effects of global warming & 26 & 41.9 \\
\hline High transportation costs & 25 & 40.3 \\
\hline High production costs & 18 & 29.0 \\
\hline Lack of information about beekeeping & 9 & 14.5 \\
\hline Decrease of crop production & 8 & 12.9 \\
\hline Non-diversification of bee products & 7 & 11.3 \\
\hline Lack of tools and equipment & 5 & 8.1 \\
\hline Problems related to breeding bees & 4 & 6.5 \\
\hline Difficulties in obtaining loans & 4 & 6.5 \\
\hline Honey analysis results do not appear & 2 & 3.2 \\
\hline Quality problems & 1 & 1.6 \\
\hline
\end{tabular}

*Total passes $100 \%$ since there are more than one answers

When the sales status of bee products is examined, it was specified that $91.9 \%$ of the farmers sold extracted honey and $16.1 \%$ sold comb honey and beeswax (Table 7).

Table 7. Number of farmers selling bee products

\begin{tabular}{c|c|c}
\hline & $\mathbf{n}$ & $\mathbf{\%}$ \\
\hline Number of farmers selling extracted honey & 57 & 91.9 \\
Number of farmers selling comb honey & 10 & 16.1 \\
Number of farmers selling beeswax & 10 & 16.1 \\
Number of farmers selling swarm & 2 & 3.2 \\
Number of farmers selling pollen & 2 & 3.2 \\
\hline
\end{tabular}

When the average sales amount of bee products were examined in the study, it was identified that the average amount of extracted honey sales of the farmers is $2323.7 \mathrm{~kg}$, the average comb honey sales amount is $75.7 \mathrm{~kg}$ and the average beeswax sales amount is $12.4 \mathrm{~kg}$ (Table 8).

The farmers' sales prices of bee products are shown in Table 9. As shown in the table, the sales price of comb honey is $5.96 €$, extracted honey is $2.16 €$, beeswax is $7.09 €$, pollen is $7.70 €$ and swarm is $77.03 €$.

Table 8. The average sales amount of bee products

\begin{tabular}{c|c}
\hline & Sales amount \\
\hline The sales amount of extracted honey $(\mathrm{kg})$ & 2323.7 \\
The sales amount of comb honey $(\mathrm{kg})$ & 75.7 \\
The sales amount of beeswax $(\mathrm{kg})$ & 12.4 \\
The sales amount of swarm (unit) & 1.6 \\
The sales amount of pollen (kg) & 3.1 \\
\hline
\end{tabular}


Table 9. Actual and expected average sales prices of bee products. (Source: TCMB, 2018)

\begin{tabular}{c|c|c|c|c}
\hline & $\begin{array}{c}\text { Sales price } \\
(\mathbf{T L})\end{array}$ & $\begin{array}{c}\text { Sales price } \\
(\boldsymbol{\epsilon})\end{array}$ & $\begin{array}{c}\text { Expected sales price } \\
(\mathbf{T L})\end{array}$ & $\begin{array}{c}\text { Expected sales price } \\
(\boldsymbol{\epsilon})\end{array}$ \\
\hline Comb honey & 23.2 & 5.96 & 45.5 & 11.68 \\
Extracted honey & 8.4 & 2.16 & 14.4 & 3.70 \\
Beeswax & 27.6 & 7.09 & 41.9 & 10.76 \\
Pollen & 30 & 7.70 & 100 & 25.68 \\
Swarm & 300 & 77.03 & 400 & 102.71 \\
\hline
\end{tabular}

*As of 15 May 20171 Euro $=3.8946$ TL

Sales prices of bee products and sales prices of bee products according to farmers are shown in Table 9. As it is seen from the table, sales prices of bee products are well below the sales prices expected by farmers. The price differences were calculated as $5.72 €$ in comb honey, $1.54 €$ in extracted honey, $3.67 €$ in beeswax, $17.89 €$ in pollen and $25.68 €$ in swarm.

Farmers' extracted honey selling areas are presented in Table 10. As it can be seen from the table, the majority of the farmers sell extracted honey to the merchant $(75.8 \%)$.

Table 10. Farmers' selling places of extracted honey

\begin{tabular}{c|c|c}
\hline & $\mathbf{n}$ & \% \\
\hline Directly to the customer & 6 & 9.7 \\
Merchant & 47 & 75.8 \\
Wholesaler & 3 & 4.8 \\
Retailer & 7 & 11.3 \\
\hline
\end{tabular}

*Total passes $100 \%$ since there are more than one answers

In this study, it is determined that $99 \%$ of the produced honey is sold while $1 \%$ is preserved for home consumption.

Reaching agricultural information at the right time has a vital importance for the success of farmers. The access of farmers to reliable, timely and necessary information will reduce the risks and uncertainties of farmers and help them to make the right decision (Mbagwu, et al., 2018). Access to agricultural marketing information of farmers and other agricultural stakeholders can be improved through accessible agricultural marketing information systems (Amer et al., 2018). Agricultural information is a critical component in increasing small-scale agricultural production and in reaching farmers' profitable markets. In the case of reaching market information by farmers, yield increase will be achieved (Wawire et al., 2017). Access to the market is one of the most important factors affecting the performance of agriculture and plays an important role in developing and diversifying the means of living of small farmers in developing countries. Inadequate access to market information leads to moral damage and high transportation costs and hence prevents some farmers from accessing the market (Okello et al., 2014). By means of reaching agricultural markets, small-scale farmers are able to increase agricultural production, realize economic growth and reduce hunger and poverty (Magesa et al., 2014). Market information flow to small-scale farmers is poor. This complicates farmers' access to the market (Matto, 2018; Wawire 
et al., 2017). In this study, when farmers' status of access to information related to domestic (market price, production, demand) and foreign (market price, production, demand) markets is examined, it was determined that $48.4 \%$ of the farmers have access to the information related to domestic market and $17.7 \%$ of the farmers had access to the information related to the foreign market.

When the extracted honey sales of the farmers is examined, it is determined that in general they sell the extracted honey in cash (69.4\%) (Table 11). Examining the months of extracted honey sales of the farmers, it draws attention that honey is sold intensively in September, October and November (Table 12).

Agricultural marketing, especially in developing countries, plays an important role in reducing poverty sustainably and ensuring household food safety (Katengeza, 2012). $83.9 \%$ of farmers were found to have problems with honey marketing when this problem was examined. Low sales price of honey (80.6\%), unfair competition (38.7\%), fluctuations in market prices $(27.4 \%)$, and inability to access market related information $(21 \%)$ are amongst the most important problems faced by farmers in honey marketing (Table 13).

\section{Discussion}

This study was carried out in order to reveal the production and marketing structures of bee products of beekeepers in Milas district of Muğla province. Farmers participating in the research can be said to be middle-aged. In a research done by Adedeji et al. (2016), it is specified that $90 \%$ of the beekeepers is in $40-49$ age range.

Table 11. Farmers' form of sale of extracted honey

\begin{tabular}{c|c|c}
\hline & $\mathbf{n}$ & $\mathbf{\%}$ \\
\hline Cash & 43 & 69.4 \\
Dated & 6 & 9.7 \\
Cash+dated & 8 & 12.9 \\
Does not sale & 5 & 8.0 \\
Total & 62 & 100.0 \\
\hline
\end{tabular}

Table 12. Farmers' sales months of extracted honey

\begin{tabular}{c|c|c}
\hline & $\mathbf{n}$ & \% \\
\hline January & 6 & 9.7 \\
February & 3 & 4.8 \\
March & 1 & 1.6 \\
April & 1 & 1.6 \\
May & 1 & 1.6 \\
June & - & - \\
July & 8 & 12.9 \\
August & 11 & 17.7 \\
September & 26 & 41.9 \\
October & 34 & 54.8 \\
November & 25 & 40.3 \\
December & 15 & 24.2 \\
\hline
\end{tabular}

*More than one answers received 
Table 13. Farmers' problems related to honey marketing

\begin{tabular}{|c|c|c|}
\hline & $\mathbf{n}$ & $\%$ \\
\hline Low sales price of honey & 50 & 80.6 \\
\hline Unfair competition & 24 & 38.7 \\
\hline Fluctuations in market prices & 17 & 27.4 \\
\hline Inability to access information about the market & 13 & 21.0 \\
\hline Lack of financial power & 11 & 17.7 \\
\hline Distrust to the trader & 10 & 16.1 \\
\hline Inadequate honey consumption of consumers & 9 & 14.5 \\
\hline Non-diversification of bee products & 5 & 8.1 \\
\hline Insufficient storage conditions & 4 & 6.5 \\
\hline Inability to receive the sales price in time & 4 & 6.5 \\
\hline Changes in consumer demand & 3 & 4.8 \\
\hline No payment in advance & 3 & 4.8 \\
\hline $\begin{array}{l}\text { The farmers cannot see the honey analysis reports due to the fact that } \\
\text { the analysis made by the companies }\end{array}$ & 2 & 3.2 \\
\hline Inability to obtain products with the same quality & 1 & 1.6 \\
\hline Insufficient support & 1 & 1.6 \\
\hline
\end{tabular}

*Total passes $100 \%$ since there are more than one answers

It was determined that the farmers participating in the study were highly experienced in beekeeping (19.5 years). In a research done by Belie (2009) in Ethiopia, average experience of the beekeepers is figured as 14.5 years. In a research done by Ceyhan and Canan (2017) average age of beekeepers is figured as 49, average experience is figured as 21 years.

In the study, it was determined that most of the farmers received loans $(64.5 \%)$. In a research done by Belie (2009), it is determined that $85 \%$ of the beekeepers take out loan.

It was determined that very few of the farmers participating in the study kept their business records regularly $(9.7 \%)$. In a research done by Mujuni et al. (2012) in Uganda, it is found that $10 \%$ of the beekeepers keep a record of hive numbers. In a research done by Şeker et al. (2017), it is pointed out that $69.1 \%$ of the beekeepers do not have a record.

It was determined that a significant number of farmers participating in the research also carried out other agricultural activities besides beekeeping. In a research done by Burucu and Bal (2018) in Kastamonu province, it is seen that $66.7 \%$ of the farmers conduct other agricultural activities than beekeeping. In a research done by Tullu (2014) in Ethiopia, it is found that the income of the farmers is supplied from beekeeping by $40 \%$, other animal activities by $33 \%$ and crop production by $27 \%$. In a research done by Abazinab et al. (2016), it is indicated that $63.4 \%$ of the income of the farmers is supplied by beekeeping activities. $8.82 \%$ of the farmers who participated in the research done by Kekeçoğlu et al. (2013) perform only beekeeping, the ones who does other agricultural activities and beekeeping activities are found to be $49.26 \%$. In a research being conducted by Kalayu et al. (2017), 27.7\% of farmer income is determined from crop production, $23.8 \%$ from animal production, $16.9 \%$ from beekeeping activity and $15.4 \%$ from irrigation. In the study conducted by Chauhan and Sharma (2000), it was 
determined that $69 \%$ of household income of farmers came from beekeeping. In a research done by John (2014) in Tanzania, 52.50\% of the farmers' basic income source was determined to be beekeeping.

High majority of the beekeepers $(88.7 \%)$ participating in the current study started the business of beekeeping with colonies in modern hives. Guyo and Legesse (2015) found that $92 \%$ of the farmers started beekeeping by trapping swarms while $7 \%$ of them started with the gift hives received from their family. In the research conducted by Tesfaye et al. (2017), it was determined that the $98.3 \%$ the farmers start beekeeping by trapping swarms and $1.7 \%$ of the farmers start with inherited hives from family. Abazinab et al. (2016) specified that $71.7 \%$ of the farmers started beekeeping via trapping swarms, while $28.3 \%$ of them started beekeeping through the gifted hives from family. In the research conducted by Gebreyohans and Gebremariam (2017), it is determined that $38 \%$ of the farmers started beekeeping through the gifted hives from family, $35 \%$ of them started via purchasing the hives and $15 \%$ of them started beekeeping using the hives retrieved from governmental and non-governmental organizations.

In the research, the most important reason for farmers to start beekeeping was determined to be obtaining yields in a short time. In the research done by Burucu and Bal (2018) in Kastamonu province, the first reason of farmers' to start beekeeping is the habit inherited from family by $67.90 \%$. In the study conducted by Tunca and Çimrin (2012), it was determined that beekeeping activities is the only source of income for $17 \%$ of the farmers and additional source of income for $\% 57$ of them. In a research conducted by Borum (2017) in South Marmara Region, it is determined that $83.75 \%$ of the farmers do beekeeping as side job and hobby. In a research conducted by Şahinler and Gül (2003) in Hatay province, it is specified that $38.95 \%$ of the beekeepers do beekeeping to make a living, $42.11 \%$ of them do it with the aim of side income and $18.95 \%$ of them pursue it as a hobby.

The colonies possessed by nearly half of the beekeepers participating in the current research have decreased in the last three years. In a research conducted by Potts et al. (2010) that involves 18 European countries, it was determined that the number of hives decreased in central European countries while it increased in some Mediterranean countries. Demir et al. (2017) found that $8.8 \%$ of the farmers were considering to leave the beekeeping in the future. In the study conducted by Çevrimli and Sakarya (2018), the rate of farmers who is considering to increase the number of bee hives in the next years was found to be $57.5 \%$.

It was determined that most of the beekeepers $(77.4 \%)$ participating in the current research perform migratory beekeeping. In a study conducted in Croatia by Barlovic et al. (2009), it was determined that one third of the farmers were migratory beekeepers. In a study conducted in India by Sharma et al. (2013), it was found that the farmers were carrying 250-300 hives to 300-800 km away. Another study by Adgaba et al. (2014) found that $93 \%$ of the farmers were migratory beekeepers.

Environment, climate and flora have important effects on the number of harvests made. Therefore, the number of harvests may vary from region to region. It was found that half of the participating beekeepers have two honey harvests a year. In a study conducted by Gebremeskel et al. (2014), the rate of farmers who harvested once a year is specified as $61.5 \%$, twice a year is $36.5 \%$ and three times a year is $1.9 \%$. In their study, Kiros and Tsegay (2017) shows that more than $70 \%$ of the farmers harvested honey once a year while $25 \%$ harvest three times a year. In a study conducted by 
Abejew and Zeleke (2017), it is specified that $34 \%$ of farmers harvest more than twice per year. In a study conducted by Abazinab et al. (2017), it is showed that the rate of farmers who harvested once a year is $37.8 \%$, twice a year is $52.8 \%$ and three times a year is $9.4 \%$. In the study conducted by Gebreyohans and Gebremariam (2017), it was found that $75 \%$ of the farmers harvested in September and October and 34.16\% in July and August.

When the literature is reviewed, it is seen that there are significant differences between the numbers of hives possessed by beekeepers because many factors can be effective on the number of hives possessed. The participating beekeepers were found to have 162 hives on average. In a study conducted by Sarab et al. (2018) in Iran the average number of hives was found as 176. In another study conducted by Kadirhanoğulları (2016) in Iğdır province, it was determined that each business has 67 units of bee hives on average. In another study conducted by Tarekegn et al. (2017), it is determined that the families doing beekeeping business has 19 hive assets on average. In the research done by Moniruzzaman and Rahman (2009), the average number of hives owned by farmers was found as 28 . In the research conducted by Kezic et al. (2008), farmers with up to 60 hives were referred as hobby beekeepers, farmers who has between 61 to 150 hives were referred as part-time beekeepers and farmers with more than 151 hives were referred as professional beekeepers. In that research, it was determined that $56 \%$ of farmers were doing beekeeping as hobby, $31 \%$ of them were part time beekeepers and $13 \%$ of them were professional beekeepers. In the study conducted by Kutlu (2014) in Gaziantep province, it is determined that the rate of farmers who consider beekeeping as the main source of income is $54 \%$, as a side income is $37 \%$ and as a hobby is $9 \%$.

Almost all of the participating farmers $(98.4 \%)$ were determined to produce honey. In the study conducted by Öztürk (2017), it was determined that $82.5 \%$ of the farmers produce only honey and $17.5 \%$ produce pollen and royal jelly besides honey production. In the study conducted by Grgic et al. (2018) in Croatia, the yield of honey per hive was found to be $18.33 \mathrm{~kg}$. In the study conducted by Y1ldırım and Ağar (2008) the yield of honey per hive was found to be $10.72 \mathrm{~kg}$. In the study conducted by Onurlubaş and Demirkıran (2017), it was determined that on average the farmers produced $2555.75 \mathrm{~kg}$ of honey annually. In the study conducted by Peter (2015), the average honey yield per hive in South Africa during the 2007/08 period is reported to be $12.77 \mathrm{~kg}$. In a study conducted by Vural and Karaman (2009) in Bursa province, the average hive asset of farmers was found to be 168.40 and the average honey production was $4527.33 \mathrm{~kg}$.

It was determined that the most important problem faced by the beekeepers during the production phase was diseases and pests. Effective and proper fight against bee diseases and pests is seen as very important in terms of the sustainability of beekeeping in the district. In other studies on the subject, diseases and pests have been found to be an important problem. In the study conducted by Ahikiriza (2016), it was concluded that limited information about production, diseases and pests, low colony assets and fires are the most important problems related to production. In a survey conducted by Yemane and Taye (2013) in Ethiopia, it was determined that the problems of beekeeping were insufficiency of beekeeping equipment, inadequate colony assets, high prices of modern hives, pests and beekeepers' lack of knowledge. In a study conducted by Ogunjimi et al. (2016) in southwest Nigeria, it was determined that the most important problems of the beekeepers regarding the production were the lack of information about beekeeping, the 
lack of loan opportunities and the existence of insufficient processing technologies.. In the study conducted by Aksoy et al. (2017) in Erzurum province, the most important factors affecting honey production are found to be unsuitable climate conditions and winter loss. In the study conducted by Gebreyohans and Gebremariam (2017), 83.3\% of the farmers stated that they see bee pastures as the most important problem especially in the dry season. In the study conducted by Ogunjimi et al. (2016), it is determined that the most important problems related to beekeeping is inadequate training related to beekeeping practices, insufficient loan opportunities and lack of beekeeping equipments.

In the current study, the most important bee product sold was found to be honey. In their study, Adedeji et al. (2016) stated that $74 \%$ of farmers produce honey for commercial purposes. In the study conducted by Burucu and Bal (2018) in Kastamonu province, it is determined that $82.72 \%$ of the farmers sell their honey.

In the research, it was determined that there were significant differences between the actual sales prices of bee products and the sales prices expected by the farmers for their products. In a research done by Kezic et al. (2008), it was found that the average selling price of honey for beekeeping professionals was $2.07 € / \mathrm{kg}$. In a study conducted by Cejvanovic et al. (2011) in Bosnia and Herzegovina the wholesale price of honey was found to be $2.11 € / \mathrm{kg}$. In a research conducted by Saner et al. (2004) in İzmir and Muğla provinces, the farmers' wholesales price of the extracted honey is calculated to be $1.65 € / \mathrm{kg}$. In a research conducted by Demir et al. (2017), it is specified that only $37.5 \%$ of the farmers were satisfied with the current honey prices. In a research conducted by Köseman et al. (2016) it is found that the rate of the farmers stating that in the last five years their beekeeping income is decreased is $38.3 \%$ while the farmers stating that their income has increased and decreased in this period is $39.6 \%$.

In the study, it was determined that high majority of the beekeepers were found to be selling their products to traders. It was specified, by Onurlubaş and Demirkıran (2017) in their study in Edirne province, that $37.5 \%$ of the honey produced by the farmers was sold directly to the consumers.

It the current study, it was also found that the amount of honey allocated to the consumption of the beekeepers' their own families is very low (1\%). In their study, Shibru et al. (2016) found that $95.8 \%$ of the farmers sold the honey immediately after the harvest while $4.2 \%$ of them stocked the honey for home use. In a study conducted by Girma et al. (2008) it is determined that $90 \%$ of the honey is sold and $10 \%$ is consumed at home. In their study Lemita (2010) found that farmers sold $97 \%$ of the produced honey in local markets for cash and 3\% of them consumed at home. In a study conducted by Kinati et al. (2013) in Ethiopia, it is determined that $75 \%$ of the honey sold after between one and six months, while $1.7 \%$ of it is stocked more than two years by the farmers. In the study conducted by Ambaw and Teklehaimanot (2018), it was determined that $39.7 \%$ of the farmers did not stock honey while $41.7 \%$ of them stocked from one to six months.

In this study, it was also determined that honey was sold in almost all months. In the research conducted by Abebe (2009) in Ethiopia it was found that farmers sold 27\% of the honey in December, $25 \%$ of it in January and $18 \%$ of it in February.

The low sales price of honey was determined as the most important problem faced by beekeepers in marketing. In the study conducted by Kadirhanoğulları (2016), it was determined that the lack of effective marketing cooperatives to market the produced honey was stated as the biggest problem of all the farmers. In a study conducted by 
Kumar (2013) in India, low honey sales prices, high cost of transporting hives from one place to another and financial difficulties experienced during the purchase of raw materials have been identified as problems by farmers.

\section{Conclusion}

Bees are vital for the continuity of the ecosystem as they ensure the pollination of plants. Beekeeping is a very important agricultural activity in terms of diversifying agricultural income and agricultural activities in rural areas and increasing agricultural income. Beekeeping has an important place both in Muğla and Milas.

The average honey production per hive in Turkey is about 14.63 kilograms (Şahin, 2015). In the research, the average extracted honey production per hive was found to be $14.41 \mathrm{~kg}$, this figure appears to be slightly less when it is compared to average production of Turkey. It is thought that productivity will increase due to the modern beekeeping techniques of the farmers. Therefore, relevant agricultural extension programs should be organized. It was determined that $87.1 \%$ of farmers had problems with honey production. Diseases and pests $(53.2 \%)$ and negative effects of global warming $(41.9 \%)$ are among the most important problems of beekeepers. Beekeeping courses should be organized in order to solve the problems of farmers related to production, to increase their technical knowledge on bee farming and diseases and pests. Farmers should be educated with practical trainings.

It is stated that $83.9 \%$ of farmers have problems with honey marketing. The most important problem farmers face with honey marketing is the low price of honey (80.6). There are no beekeeping cooperatives in the research area. This reduces the bargaining power of beekeepers and beekeepers sell bee products at low prices. In the research, it was determined that the sales prices of bee products were significantly lower than the sales prices expected by farmers. On the other hand, it has been determined that the farmers' rate of accessing information about market is low. In addition to the beekeeping techniques, farmers have to know and follow supply, demand, domestic and foreign markets, sales, price formation etc. closely. Agricultural marketing extension can be defined as a training program that provides information that farmers need to solve marketing problems. Therefore, an agricultural marketing extension program should be applied to meet farmers' needs, and farmers' problems about the market should be solved.

\section{REFERENCES}

[1] Abazinab, M., Debele, K., Worku, Z. (2016): Assessment of beekeeping practices in Shabe and Seka Chekorsa districts of Jimma zone, Southwestern Ethiopia. - European Journal of Biological Sciences 8(2): 45-55.

[2] Abebe, A. (2009): Market chain analysis of honey production: in Atsbi Wemberta District, Eastern Zone of Tigray National Regional State. - M.Sc. Thesis. College of Agriculture Department of Agricultural Economics, School of Graduate Studies Haramaya University.

[3] Abejew, T. A., Zeleke, Z. M. (2017): Study on the beekeeping situation, the level of beekeepers knowledge concerning local honeybee subspecies, their productive characteristics, and behavior in Eastern Amhara Region, Ethiopia. - Advances in Agriculture. https://doi.org/10.1155/2017/6354250. 
[4] Adedeji, N. K., Joseph, O. O. (2016): An assessment of profitability of honey production in Edo State, Nigeria. - African Journal of Agricultural Economics and Rural Development 4(6): 442-445.

[5] Adgaba, N., Al-Ghamdi, A., Shenkute, A. G., Ismaiel, S., Al-Kahtani, S., Tadess, Y., Ansari, M. J., Abebe, W., Abdulaziz, M. Q. A. (2014): Socio-economic analysis of beekeeping and determinants of box hive technology adoption in the Kingdom of Saudi Arabia. - The Journal of Animal \& Plant Sciences 24(6): 1876-1884.

[6] Ahikiriza, E. (2016): Beekeeping as an alternative source of livelihood in Uganda. Master Thesis. Faculty of Bioscience Engineering, Gent University.

[7] Aksoy, A., Sar1, M. M., Terin, M. (2017): Economic structure of beekeeping sector in Erzurum province. - Turkish Journal of Agricultural and Natural Sciences 4(4): 434-440.

[8] Ambaw, M., Teklehaimanot, T. (2018): Characterization of beekeeping production and marketing system and major constraints, in selected districts of Arsi and West Arsi zones of Oromia region in Ethiopia. - Journal of Entomology and Zoology Studies 6(2): 24082414.

[9] Amer, J. N., Odero, D., Kwake, A. (2018): Towards improving agricultural marketing information systems for smallholder farmers: a Tharaka Nithi case. - Journal of Agriculture and Sustainability 11(2): 99-128.

[10] Anonymous (2004): Mugla Agriculture Master Plan. - Ministry of Agriculture and Rural Affairs, Muğla Province Directorate of Agriculture, Mugla.

[11] Anonymous (2005): Turkish Food Codex Communiqué on Honey (2005/49). - Official Gazette (No. 26026) (in Turkish).

[12] Anonymous (2015): Milas Capital of Civizilation. - Milas Municipality Publication (in Turkish).

[13] Arbuckle, J. G., Morton, L. W., Hobbs, J. (2013): Farmer beliefs and concerns about climate change and attitudes toward adaptation and mitigation: Evidence from Iowa. Climatic Change 118: 551-563.

[14] Barlovic, N., Kezic, J., Bedenik, N. O., Grgic, Z. (2009): Economic efficiency of beekeeping in Croatia. - Agriculturae Conspectus Scientificus 74(1): 51-54.

[15] Belie, T. (2009): Honeybee production and marketing systems, constraints and opportunities in Burie District of Amhara Region, Ethiopia. - Master Thesis, Department of Animal Science and Technology, School of Graduate Studies, Bahir Dar University, Ethiopia.

[16] Borum, A. E. (2017): A study of beekeeping survey in southern Marmara Region of Turkey. - Uludag Bee Journal 17(1): 24-34 (in Turkish).

[17] Burucu, V., Bal, H. S. G. (2018): Marketing opportunities of beekeeping farms: a case of Azdavay district of Kastamonu Province. - The Journal of Agricultural Economics Researches 4(1): 23-35 (in Turkish).

[18] Çakar, Ö., Durmuş, E., Arslan, H. (2011) The place of Milas district in Muğla olive production. - Firat University Journal of Social Science 21(1): 1-26 (in Turkish).

[19] Cejvanovic, F., Grgic, Z., Maksimovic, A., Bicanic, D. (2011): Assumptions of economic model for sustainable productions of beekeeping in the Bosnia and Hercegovina. Journal of Agricultural Science and Technology 5(4): 481-485.

[20] Çevrimli, M. B., Sakarya, E. (2018): Structural characteristics and problems of beekeeping enterprises in Aegean Region example. - Eurasian Journal of Veterinary Sciences 34(2): 83-91 (in Turkish).

[21] Ceyhan, V., Canan, S. (2017): Economic performance of beekeepers under different colony management system in Turkey. - Turkish Journal of Agricultural and Natural Sciences 4(4): 516-522 (in Turkish).

[22] Chauhan, S. K., Sharma, S. K. (2000): A Study on Employment and Income Generating Potential of Apicultural Products in Himachal Pradesh. - Department of Agricultural Economics H P Krishi Vishvavidyalaya, Palampur. 
[23] Çukur, F., Yücel, B., Demirbaş, N. (2016): Food safety applications towards beekeeping activities in the EU and Turkey: problems and suggestions. - Turkish Journal Agricultural Economics 22-2: 87-95 (in Turkish).

[24] Demir, P. A., Aydın, E., Yazıc1, K., Kırmızıbayrak, T. (2017): Problems and expectations of beekeeping enterprises in Ardahan Province. - Eurasian Journal of Veterinary Sciences 33(4): 260-267 (in Turkish).

[25] FAO (2018): Livestock Primary. - http://www.fao.org/faostat/en/\#data/QL. Access date: 04.12.2018.

[26] Gebremeskel, Y., Tamir, B., Begna, D. (2014): Characterization of bee-keeping systems and honey marketing in Eastern zone Tigray, Ethiopia. - Livestock Research for Rural Development 26(10): 1-7.

[27] Gebreyohans, K. W., Gebremariam, T. T. (2017): Beekeeping management practices and constraints in Eastern Tigray, Ethiopia. - Journal of Agriculture and Environment for International Development 111(2): 323-342.

[28] Girma, M., Ballo, S., Tegegne, A., Alemayehu, N., Belayhun, L. (2008): Approaches, methods and processes for innovative apiculture development: Experiences from Ada'aLiben Woreda, Oromia Regional State, Ethiopia. - International Livestock Research Institute, Working Paper No. 8.

[29] Grgic, Z., Filipi, J., Bicanic, D., Bobic, B. S. (2018): Opportunities for developing a business model of Mediterranean beekeeping. - Journal of Central European Agriculture 19(1): 206-216.

[30] Guyo, S., Legesse, S. (2015): Review on beekeeping activities, opportunities, challenges and marketing in Ethiopia. - Journal of Harmonized Research in Applied Sciences 3(4): 201-214.

[31] John, J. (2014): Organising beekeepers to generate income from bee products in Solya Ward, Manyoni District Tanzania. - Master Thesis. Open University of Tanzania.

[32] Kadirhanoğulları, İ. H. (2016): Economic analysis of apiculture in Igdir Province. - Msc Thesis. Igdir University Graduate School of Natural and Applied Sciences Department of Agricultural Economics, Igdir (in Turkish).

[33] Kalayu, A., Wondifraw, Z., Tiruneh, W. (2017): Beekeeping practice and honey production in north-east dry land areas of Amhara national regional state, Ethiopia. Poultry, Fisheries \& Wildlife Sciences 5(2): 1-12.

[34] Katengeza, S. (2012): ICT-based market information services, operational environment and performance: the case of Malawi agricultural commodity exchange and food and nutrition security joint task force. - American International Journal of Social Science 1(2): 34-43.

[35] Kekeçoğlu, M., Rasgele, P. G., Acar, F., Kaya, S. T. (2013): Investigation of colony losses, honey bee diseases and pests and fighting methods seen in the beekeeping enterprises in the province of Duzce. - Journal of the Institute of Science and Technology 3(3): 99-108 (in Turkish).

[36] Kezic, J., Bobic, B. S., Svecnjak, L., Drazic, M., Grgic, Z., Kezic, N. (2008): Economic evaluation of beekeeping in Karlovacka county. - Journal of Central European Agriculture 9(3): 615-620.

[37] Kinati, C., Tolemariam, T., Debele, K. (2013): Assessment of honey production and marketing system in Gomma district, south western Ethiopia. - Greener Journal of Business and Management Studies 3(3): 99-107.

[38] Kiros, W., Tsegay, T. (2017): Honey-bee production practices and hive technology preferences in Jimma and Illubabor Zone of Oromiya Regional State, Ethiopia. - Acta Universitatis Sapientiae Agriculture and Environment 9: 31-43.

[39] Köseman, A., Şeker, İ., Karlıdağ, S., Güler, H. (2016): Beekeeping activities-I the demographic characteristics of beekeepers, the problems of beekeeping and the determination of the views of beekeepers related to current administrative and economic applications. - Kocatepe Vet. J. 9(4): 308-321(in Turkish). 
[40] Kumar, Y. (2013): A Multi-Dimensional Study on Production and Management System of Apiculture Farming in Jammu Region. - Division of Agricultural Extension Education Sher-e-Kashmir University of Agricultural Sciences \& Technology of Jammu.

[41] Kutlu, M. A. (2014): Determining the current status of Gaziantep province its beekeeping problems and solutions. - Turkish Journal of Agricultural and Natural Sciences 1(4): 481484 (in Turkish).

[42] Lemita, S. K. (2010): Factors affecting honey pricing in domestic supply chain - the case of the Konso District, Ethiopia. - Master Thesis. Van Hall Larenstein University of Applied Sciences, Wageningen, The Netherlands.

[43] Malisa, G. G., Yanda, P. (2015): Impacts of climate variability and change on beekeeping productivity. - The 1st Continental Symposium on Honey Production, Bee Health And Pollination Services in Africa, Cairo, Egypt.

[44] Matto, G. (2018): Agricultural information access and the use of icts among smallholder farmers: A case of Bembeke EPA in Dedza District, Malawi. - Research Report Series 2(1): 59-72.

[45] Mbagwu, F. C., Benson, O. V., Onuoha, C. O. (2018): Challenges of Meeting Information Needs of Rural Farmers through Internet-Based Services: Experiences from Developing Countries in Africa. - IFLA WLIC 2018, Kuala Lumpur, Malaysia.

[46] Moniruzzaman, M., Rahman, M. S. (2009): Prospects of beekeeping in Bangladesh. - J. Bangladesh Agril. Univ. 7(1): 109-116.

[47] Mujuni, A., Natukunda, K., Kugonza, D. R. (2012): Factors affecting the adoption of beekeeping and associated technologies in Bushenyi District, Western Uganda. Livestock Research for Rural Development 24(08).

[48] Newbold, P. (1995): Statistics for Business and Economics. - Prentice-Hall International, New Jersey.

[49] OGM (The Ministry of Forestry and Water Affairs General Directorate of Forestry). (2013): Honey Forestry Action Plan 2013-2017. - General Directorate of Forestry, Ankara (in Turkish).

[50] Ogunjimi, S. I., Ajala, A. O., Egbunonu, C. (2016): Assessing the knowledge level of beekeepers on improved beekeeping management practices in peri-urban areas of Southwestern Nigeria. - Journal of Agricultural \& Food Information, 17(2-3): 162-173.

[51] Okello, J. J., Kirui, O. K., Gitonga, Z. M., Njiraini, G. W., Nzuma, J. M. (2014): Determinants of awareness and use ict-based market information services in developingcountry agriculture: the case of smallholder farmers in Kenya. - Quarterly Journal of International Agriculture 53(3): 263-282.

[52] Onurlubaş, E., Demirkıran, S. (2017): Solution proposals for Edirne beekeeping business production and marketing problems. - J. of Academic Overlook 60: 105-124 (in Turkish).

[53] Öztürk, A. İ. (2017): Determination of technical characteristics of beekeeping in Ula county of Muğla. - Journal of Animal Production 58(2): 52-57 (in Turkish).

[54] Peter, L. (2015): Socio-Economic Factors influencing apiculture in the Eastern Cape Province, South Africa. - Master thesis. Department of Agricultural Economics \& Extension, Faculty of Science and Agriculture, University of Fort Hare.

[55] Potts, S. G., Roberts, S. P. M., Dean, R., Marris, G., Brown, M. A., Jones, R., Neumann, P., Settele, J. (2010): Declines of managed honey bees and beekeepers in Europe. Journal of Apicultural Research 49(1): 15-22.

[56] Reddy, P. V. R., Verghese, A., Rajan, V. V. (2012): Potential impact of climate change on honeybees (apis spp.) and their pollination services. - Pest Management in Horticultural Ecosystems 18(2): 121-127.

[57] Şahin, Z. (2015): Pine Honey Production Areas Report. - Our Forests and Beekeeping Workshop 1, Bolu (in Turkish).

[58] Şahinler, N., Gül, A. (2003): Structural analysis of beekeeping in Hatay province, problems and their resolution. - Journal of Agricultural Faculty, MKU 8(1-2): 105-118 (in Turkish). 
[59] Saner, G., Engindeniz, S. Tolon, B., Cukur, F. (2004): The economic analysis of beekeeping enterprises in sustainable development: A case study of Turkey. - Apiacta 38: 342-351.

[60] Sarab, M. M., Iravani, H., Fami, H. S. (2018): Identifying factors affecting beekeepers empowerment of Alborz Province. - Revista Publicando 14(2): 449-459.

[61] Şeker, İ., Köseman, A., Karlıdağ, S., Aygen, S. (2017): Beekeeping activities II: the evaluation of beekeeping activities in terms of beekeeper preferences, production quality and bee diseases in Malatya Province. - Journal of Tekirdag Agricultural Faculty 14(02): 54-63 (in Turkish).

[62] Sharma, D., Abrol, D. P., Ahmad, H., Srivastva, K., Vir, V. (2013): Migratory Beekeeping in Jammu and Kashmir, India. - World Beekeeping 44-47.

[63] Shibru, D., Asebe, G., Megersa, E. (2016): Identifying opportunities and constraints of beekeeping: the case of Gambella Zuria and Godere Weredas, Gambella Regional State, Ethiopia. - Entomology, Ornithology \& Herpetology: Current Research 5(3): 1-6.

[64] Tarekegn, K., Haji, J., Tegegne, B. (2017): Determinants of honey producer market outlet choice in Chena District, southern Ethiopia: A multivariate probit regression analysis. Agricultural and Food Economics 5(20): 1-14.

[65] TCMB (The Central Bank of the Republic of Turkey) (2018): Indicative Exchange Rates Bulletin No. 2017/95. - https://www.tcmb.gov.tr. Access date: 04.12.2018.

[66] Tesfaye, B., Dadi, G., Gelgelu, T. (2017): Assessment of honeybee enemies (pests and predators) in Bale zone, southeastern Ethiopia. - Journal of Agricultural Extension and Rural Development 9(4): 53-61.

[67] Tullu, M. B. (2014): Assessment of Honey Quality Gap: The Case of Smallholder Farmers of Sheka Zone, Anderacha District, Southwestern Ethiopia. - Van Hall Larenstein University of Applied Sciences, Wageningen, The Netherlands.

[68] Tunca, R. İ., Çimrin, T. (2012): The survey study on honey bee breeding activities in Kirsehir province. - Iğdır Univ. J. Inst. Sci. \& Tech. 2(2): 99-108 (in Turkish).

[69] TSI (2018): Animal Husbandry Statistics. https://biruni.tuik.gov.tr/medas/?kn=92\&locale=tr. Access date: 04.12.2018.

[70] Vural, H., Karaman, S. (2009): Socio-economic analysis of beekeeping and the effects of beehive types on honey production. - Notulae Botanicae Horti Agrobotanici Cluj-Napoca 37(2): 223-227.

[71] Wawire, A. W., Wangia, S. M., Okello, J. J. (2017): Determinants of use of information and communication technologies in agriculture: the case of Kenya agricultural commodity exchange in Bungoma county, Kenya. - Journal of Agricultural Science 9(3): 128-137.

[72] Yemane, N., Taye, M. (2013): Honeybee production in the three agro-ecological districts of Gamo Gofa zone of southern Ethiopia with emphasis on constraints and opportunities. - Agriculture And Biology Journal of North America 4(5): 560-567.

[73] Yildırım, İ., Ağar, S. (2008): The influence of scale on the profitability of honey beekeeping enterprises in eastern part of Turkey. - Asian Journal of Animal and Veterinary Advances 3(5): 314-320.

[74] Y1lmaz, B. (2015): Beekeeping in Turkey. - Our Forests and Beekeeping Workshop 1, Bolu (in Turkish). 